ELORE (ISSN 1456-3010), vol. 19 - 1/2012.

Julkaisija: Suomen Kansantietouden Tutkijain Seura ry.

[http://www.elore.fi/arkisto/1_12/raninen-siiskonen.pdf]

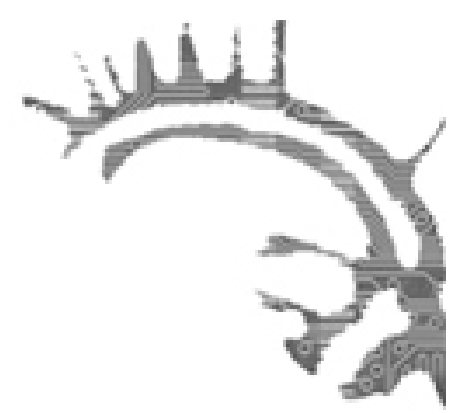

KIRJA-ARVIO

\title{
KANSANPARANNUSTA POHJOIS-KARJALASSA
}

PIELA, ULLA 2010: Kansanparannuksen kerrotut merkitykset Pobjois-Karjalassa 1800- ja 1900-luvuilla. Publications of the University of Eastern Finland. Dissertations in Education, Humanities, and Theology 8. Joensuu: University of Eastern Finland. 331 sivua.

\section{Tarja Raninen-Siiskonen}

Ulla Pielan perinteentutkimuksen väitöskirjan teema sivuaa suomalaisen yhteiskunnan ajankohtaisia puheenaiheita. Maakuntia ravisuttava kuntauudistus on tulossa. Monen asiantuntijan mukaan kuntaliitosten sijasta tulisi keskustella terveyspalvelujen uudelleen järjestämisestä, sillä kuntien käyttömenoista yli puolet kohdistuu sosiaalija terveyspalveluihin. Kansalaisten huolena ovat terveyspalvelujen taso ja saatavuus suurten taajamien ulkopuolella. Myös vaihtoehtoiset hoitomuodot ovat lisääntyneet ja yhä useampi hakee apua vaivoilleen milloin kuppauksesta, milloin akupunktiosta tai erilaisista luontaisista hoidoista.

Pielan väitöskirjassa minua kiinnosti valittu tutkimusalue: Pohjois-Karjala. Millaisen kuvan tekijä antaa täkäläisistä ihmisistä, heidän maailmankuvastaan ja kansanparannuksen muutoksista?

\section{Aineisto ja metodit}

Piela jatkaa teoksessaan Elias Lönnrotin viitoittamaa tutkimuslinjaa kansanlääkinnän ja tautikäsitysten tutkimisessa. Artikkeliväitöskirjan tutkimusalueena on Pohjois-Karjala, koska maakunnasta on saatavilla runsaasti aineistoa vuosien 1816-2002 väliltä. Perusaineisto on verraten laaja käsittäen 2110 kansanlääkinnästä kertovaa tekstiä. 
Tarja Raninen-Siiskonen: Kansanparannusta Pohjois-Karjalassa

Tutkimusmateriaalin muodostavat Suomen Kansan Vanhat Runot -teoksissa julkaistut parannusloitsut ja niihin liittyvät parannustapojen, taikojen ja riittien kuvaukset. Toinen aineisto on kerätty sanomalehti Karjalaisen ja Joensuun yliopiston Karjalan tutkimuslaitoksen kanssa vuonna 1974 ja kolmas aineisto Karjalaisen ja Suomalaisen Kirjallisuuden Seuran lukijakilpailun avulla vuosina 2001-2002.

Kansanparannus määritellään teoksessa yhteisön sosiaalisessa vuorovaikutuksessa ilmeneväksi kulttuuriseksi tiedoksi ruumiista ja sen ulkopuolella olevan todellisuuden suhteesta. Väitöskirjan pääkysymys kuuluu: "Miten parantamiseen liittyvät perinnetekstit ilmentävät pohjoiskarjalaisten tulkintoja terveydestä ja sairaudesta sekä niissä tapahtuneita muutoksia agraarisen Suomen modernisoituessa?" Teoksen nimen kaksoismerkityksellä viitataan siihen, millaisia merkityksiä terveydestä ja sairaudesta on tuotettu kertomalla ja toisaalta siihen, kuinka kontekstisidonnainen kerronnan merkitys on.

Tutkimukselliset lähtökohdat liittyvät hermeneutiikkaan, konstruktivismiin ja Paul Ricoerin teoriaan kulttuurisen kompetenssin narratiivisesta prosessoitumisesta, mimesikesestä. Tutkimuksen menetelmiä ovat lähiluku ja hermeneuttinen analyysi. Metodologisesti käytetään Jerome Brunerin narratiivi-käsitettä ja A.J. Greimas'n teoriaa binaarisista vastapareista. Tutkimuksessa sivutaan montaa tieteenalaa: niin kalevalamittaisen runouden, kertomusten kuin lääketieteellisen antropologian sekä etnomedisiinan alueita. Tutkija lupaa teoksen "tuovan uutta tietoa parannustapahtumaan liittyvästä kerronnasta, kulttuurista ajattelua muokkaavista kognitiivista jäsennyksistä sekä Pohjois-Karjalassa tapahtuneista terveys- ja sairauskäsitysten muutoksista.” (s. 6.)

\section{IDÄN JA LÄNNEN EROT}

Julkaisu koostuu seitsemästä artikkelista, joista vanhin on vuodelta 1983, seuraava vuodelta 1990 ja loput viisi 2000-luvulta. Kahdessa ensimmäisessä artikkelissa ollaan hieman etäämmällä pohjoiskarjalaisesta yhteisöistä ja luodaan eroa Itä- ja Länsi-Suomen välille. Ensimmäisen ja ajaltaan vanhimman artikkelin keskiössä on juvalainen Matti Immoinen ja hänen loitsunsa. Piela nostaa esiin itäisiltä alueilta tallennettujen loitsujen muuntelevuuden: loitsuja voidaan varioida rakenteellisesti, muodollisesti ja sisällöllisesti. Variointi johtuu parannusriitin luonteesta, sillä jokainen parannustapahtuma on ainutkertainen, kahden henkilön välinen vuorovaikutussuhde.

Idän ja lännen vastakohtaisuuksia pohditaan myös psyykkisen tai sosiaalisen vaivan parantamista koskevassa artikkelissa. Siinä Piela kuvaa, kuinka lemmennostatusloitsujen tai -taikojen avulla on tuotettu yhteisön arvoihin soveltuvaa naiseutta. Suullisen perinteen katsotaan vahvistavan myös yhteisössä vallitsevia stereotypioita. LänsiSuomessa varallisuus ja sosiaalinen asema näkyivät loitsujen ilmaisuissa: ne olivat lyhyitä, suorasanaisia sekä jäljittely- ja kosketustaikuuteen perustuvia. Itä-Suomessa loitsut sen sijaan suoritettiin nuorelle naiselle itselleen ja ne nähtiin sekä puhdistusettä siirtymäriittinä naiseuteen ja seksuaalisuuteen. 


\section{Sissonen Ja KaINUlaineN}

Pohjoiskarjalaisista taitajista Piela esittelee Ilomantsissa asuneen Simana Sissosen (1786-1848) ja Kesälahden Hummovaarassa vaikuttaneen Juhana Kainulaisen (1788-1847). Molemmissa artikkeleissa mennään ihailtavan syvälle perinteentaitajan repertoaariin ja kerronnan erilaisiin rajoihin. Sissosen loitsuissa liikuttiin kerronnallisesti eri aikakäsitteissä. Parantaja ylitti loitsuissaan myös symbolisesti ajan ja paikan. Menettelyllä hän pyrki osaltaan helpottamaan sairaan kipukokemuksia.

Juhana Kainulainen oli Elias Lönnrotin vuonna 1828 tapaama ensimmäinen laulaja. Lönnrot rakensi kuvaa valistuneesta talonpojasta, kun taas Kainulaisen suku kertoo hänen olleen myös tietäjä ja parantaja. Kainulaisen pihapiirin lähettyvillä on edelleen nähtävissä uhrikivet. Kainulaisen runoudessa tulee esiin agraarinen kyläkulttuuri, jossa erottuvat "tämä maailma" eli ihmisen kotipiiri sekä yliluonnollisten olentojen "vastamaailma".

\section{KANSANPARANNUS KESKIÖSSÄ}

Teoksessa rakennetaan kuvaa siitä, kuinka 1800-luvulla sairauden lähteen uskottiin löytyvän oman kodin ulkopuolella olevasta pahasta, yliluonnollisesta maailmasta. 1900-luvulla vaikutti vielä uskomus "mistä tauti, sieltä parannus" eli vaivat olivat syntyneet kotipiirissä oman työn ja toiminnan seurauksena. Meidän aikanamme taas katsotaan sairauksien olevan elinten rakenteellisia ja toiminnallisia häiriötiloja tai ympäristön vaikutusta ihmisen psyykeen.

Pohjoiskarjalainen kansanparannus on Pielan mukaan muuttunut suomalaisen yhteiskunnan modernisoitumisen ja terveydenhuoltohenkilökunnan lisääntymisen takia. Toki teos antaa tietoa pohjoiskarjalaisesta kansanparannuksesta sekä itse parannustapahtumaan että tekstien narratiiviin vaikuttaneista seikoista. Eniten painottui itäisen kulttuurimallin säilyminen läpi vuosisatojen: vaikka ympärillä oleva yhteisö on kokenut muutoksia, niin perusta on pysynyt samana. Piela pääsee teoksessaan syvälle pohjoiskarjalaiseen mielenmaisemaan ja kulttuuriin. Kansanparannus ja -runous ovat täällä säilyneet hyvin pitkään elinvoimaisina. Osaltaan siitä kertoo se, että esimerkiksi Pohjois-Karjalan museosta löytyy yllättävän runsaasti kansanlääkintään liittyvää esineistöä.

Artikkelit on julkaistu pitkän aikavälin, 23 vuoden, aikana. Lisäksi kaikki artikkelit ovat saman kustantajan julkaisemia. Vaikka kansallisia tieteitä suunnataan pääasiassa kotimaisille lukijoille, olisi toivonut edes yhden artikkelin ilmestyneen kansainvälisessä sarjassa. Aihe on mielenkiintoinen myös kansainvälisesti, joten eikö olisi kannattanut kohdentaa aihetta myös laajemmalle yhteisölle?

Filosofian tohtori Tarja Raninen-Siiskonen toimii Joensuun museoiden museonjohtajana. 